Chapter 6

\title{
Women and the Emergence of the Arabic Novel
}

\author{
Marilyn Booth
}

\section{Gender, Reading and the Early Arabic Novel}

In December 1871, the Beiruti cultural and political magazine Al-Jinān (est. 1870) published an article on "Al-Tarbiya" (the training of children), by Mrs. Wastīn Masarra, wife of Salīm Afandī Hamawī, who had "permitted me to read your periodical" (56). She issued a summons to literate women, while her article enacted an agential process of becoming a writer: she turned to reading from domestic need, including arguments with her husband, and to writing because she wanted her experience to create public benefit. What inspired Masarra was reading women's bylines in Al-Jinān, such as the story, "Hinrī wa-Imīliyā" (1870, Henry and Amelia), by Idlīd (Adelaide) alBustānī, the daughter of Al-Jinān's founding editor. ${ }^{1}$ Idlīd's younger sister Alīs (Alice, 18701926), became one of the Arab world's first female novelists.

Signaling the importance of encouragement-by-example in a writing community of women, Masarra pointed to other aspects of women's relationships to fiction from the earliest decades of the Arabic novel's existence: linkages between fiction and issues of gendered behavior, education, and who should read; the experiential grounding of women's fiction writing and the salience of its plots to female readers, but also sensitivities around fiction and reading; the creation of readerships that invoked gender solidarities; and periodicals' importance as venues for publishing and debating fiction. Masarra's letter suggested that, framing their writing as socially responsible intellectual activism, women also found writing for publication a frightening prospect that demanded a modesty discourse. When women spoke of their "shortcomings" and "inabilities" as writers (as did Masarra), they reminded readers how limited were the opportunities for female education and the sustained observation of social worlds that compelling writing demanded. A modesty discourse grounded in social expectations about women's public reticence also cannily foregrounded their expressive abilities. Since Al-Jinān encouraged submissions from women (though Masarra wondered why more had not appeared), she decided to write, "even though I am not amongst this arena's eloquent knights, nor able to sally forth to competitors' fights; I seek pardon for stumbling where literary thoroughbreds do 
not, or if I've not offered a style finely wrought" (54). Masarra's rhymed prose showed she knew prevailing requirements for "style finely wrought."

The story by Idlīd al-Bustānī to which Masarra referred is the sole extant signed and published female-authored Arabic fictional text before the late 1880s. Between 1888 and the onset of World War I, women put their names to at least thirteen original novelistic texts and eight translated novels. Women's participation in the early Arabic novel (including translations) demonstrates a shared array of themes and narrative strategies, illustrated below by nine novels published in 1888-1912, by six authors. ${ }^{2}$ These were produced in the cultural hubs of nineteenthcentury Arab life: Beirut, Cairo, Alexandria, and New York. Readers' letters tell us the spokes reached far: readers existed in provincial towns and the countryside, as education expanded in Ottoman Syria and Egypt, and in Europe and the Americas, where emigrants headed fleeing political strife, repression, and economic hardship, conditions represented in women's fiction.

Women's engagement in producing the early Arabic novel is not just about their authorship. Like Masarra's letter, it is also about readerships, girls' education, venues, sensitivities, and gender difference as a topic in public discourse. In Arab capitals as elsewhere, the novel emerged as part of an ongoing process of socio-political change; emerging notions of subjectivity entwined with new technologies and state-led institutional development fostered "a modification of representations of the world and a profound transformation of the system of symbolic production" (Hallaq and Toelle 13). The same process bolstered the novel's strong association with changing configurations of male-female social relations (perhaps more in discourse than in reality) and publicly aired concerns about gendered behaviors. Of course, the novel's forte as a form - tracing the intimate and conflicted trajectories of human individuals in community - is bound to illuminate questions of gendered identities and relations. But the ways these topics were inflected in early Arabic novels reflected the fact that gender politics was central to debates on modernity, political freedom, sociality and nation formation amongst the Arab intelligentsia. Such questions - and how gender-definition articulated them-were at the heart of the Arabic novel from its inception.

The beginnings of the Arabic novel have been variously ascribed, from 1858 when Khalīl al-Khūrī's newspaper, Hadīqat al-akhbār, featured serialized fiction; to Al-Jinan's publishing of novels by Salīm al-Bustānī (1848-84, Idlīd's and Alīs's brother) and Nu'mān al-Qasātịlī (18481920); to the 1890s, with Jurjī Zaydān's (1861-1914) historical novels, or later. Though it has 
been asserted that the first Arabic novel was authored by a woman, when women began to publish novels the genre was already a presence. ${ }^{3}$ Women as readers, writers, and translators of fiction had to contend with limitations in publishing venues, attitudes towards fiction, and men's fictional representations of, and public debates about, women's capabilities, needs, and aspirations. Writing in 1871, Masarra looked forward, maintaining her metaphor of the female knight: "I told myself: there must come a day in which we cast off this distressing fear and gallop into the arenas of literature with our words and our deeds, when crowds of women vie to publish the beneficial works their talents exude" (54). By 1913, the arena of women's fiction was not yet crowded but it was inhabited and claimed, one of several genres in which women articulated their views on self and society amidst the stresses of late colonial modernity.

\section{Venues}

The relationship between the production and marketing of novels and a discourse on novel writing and reception in the Arabic press and in prefaces to novels bears directly on feminine involvement in the form. Women who sought to write novels were aware of the fraught debate they entered. From its beginnings, the non-official Arabic press published fiction: from Hadiqat al-akhbār and Al-Jinān to political newspapers such as Al-Ahrām (est. 1876), where Sa'īd alBustān̄̄’s (d. 1901) Dhāt al-khidr (1884, The Secluded Woman) appeared. Monthly miscellanies, famously Zaydan's Al-Hilāl (est. 1892), published their editors' and others' fictions. Novelreading's popularity shows in the slew of periodicals founded from 1884 to publish fiction, like Muntakhabāt al-riwāya (est. 1894), or Musāmarāt al-sha 'b (1904-11), whose editor Khalīl Șādiq chose a title evoking a long-attested cultural practice, musāmara as the convivial evening session where stories were told and events explicated, to label his vehicle for this new technology of entertainment called al-riwāya (narrative, narration, novel) or al-rūmān (French roman, romance, novel). Musāmara and riwāya indicated continuity with oral storytelling forms; musāmara also suggested continuity between audiences for oral storytelling and the new popular-romantic tales of these periodicals. This is important because writing women and men drew on structures and motifs of oral storytelling. These serials were not where women generally published (at least not under their own names). But the commercialization of literary fiction may have helped to form an audience for women's novels, while contributing to the "social stigma" that accompanied the early Arabic novel (Allen 26). 
Women's magazines, first appearing in 1892, took an active interest in fiction, publishing it and commenting on new novels. Almost every month, in its "Books" column, the women's magazine Anīs al-jalīs (est. 1898) announced new novels, highlighting their attention to “women's state." In May 1902, the magazine heralded Al-Ghāda al-sūriyya (1902, The Syrian Maiden) a "literary and amatory novel by Qayșar Afandī al-Ma 'lūf [1874-1964], editor of the periodical Al-Barāzīl [Brazil]." Anīs al-jalīs lauded Ma'lūf's novel pointedly. "While providing entertainment, it investigates conditions of the eastern young woman, shows clerics' intrusiveness in Syria, and describes Syrian immigrants' status in Brazil: its author deserves praise" ("Kutub" 1902).

Editing magazines, women were no less likely than men to publish their own fiction. Aliksandra Khūrī Afīrīnū (Alexandra Avierino, 1872-1926), founding editor of Anīs al-jalīs, published her translation Shaqā' al-ummahāt (1900, The Misery of Mothers) serially. Typically for the period, she did not name the source author or title. In volume 3 (1900), she announced that the novel was available, bound, from the magazine's office: "with its exemplary lessons we were glad it was well-received" ("Kutub" 1900). ${ }^{4}$ Labība Hāshim (c1880-1947) published her eponymous novella Shīrīn (1906-7) in her new journal, Fatät al-sharq (est. 1906). She had published translated short stories in Beirut's Al-Diy $\bar{a}^{\prime}$ (est. 1899) and her journal included a strong fictional component from the start. ${ }^{5}$ After Shìrin's final chapter appeared, the editor noted that "in response to writers' wishes, we have published Shìrin as its own book ... thirty-two pages and sold at al-Ma'ārif Bookstore in Fajjāla for one piastre" (“Āthār”).

\section{The Active Reader and Debates on Women}

Periodical readers demanded fiction. In 1895, Jurjī Zaydān, already emerging as the era's leading historical novelist, reminisced that, founding Al-Hiläl three years before, he had "resolved to devote a section to historical novels" and published his Istibdäd al-mamālīk (1893, Despotism of the Mamluks) there. "Then we decided to change course, so we published volumes two and three without a novel. A group of reader-litterateurs urged us to return to our initial resolve" ("Muqaddima" 23). Similar pressures emerge in women's magazines' rhetoric. Wishing readers farewell on its first issue's last page, Anīs al-jalīs referred defensively to fiction's absence: "We intended to initiate our magazine with an elegant, charming, and refined novel by a famous 
writer, but we had so much other material we were obliged to include. We promise our readers, male and female, to place one in the next issue or the one after, God willing."

Fiction was popular and that was the problem: ambivalence, defensiveness, and unease prevailed in discussions over the projected effects of fiction reading. As journals welcomed fiction, a debate on its consumption arose; as in the novel's history everywhere, the discourse concentrated on girls and young women as epitomizing the dangerously impressionable, corruptible reader. This concern intersected with other sensitivities: "unprotected" young women, newspapers warned, were adopting new habits and haunting the streets. Issues of "honor" as focused on the female body infused attitudes to fiction writing, while the new Arabic novels enacted these issues. That the late nineteenth century saw the founding of many private presses was a factor: it was a new phenomenon to have long printed works available inexpensively to an audience expanding as more schools opened. As long narratives that encouraged individual reading, novels induced particular parental anxiety, as mothers and fathers observed their daughters ensconced in another world.

Some commentators were implacably against fiction, linking it explicitly to sexuality and warning of danger. The Egyptian moralist-translator (of nonfiction) Aḥmad Fatḥ̄ Zaghlūl (18621914) compared novels to an ancient presence in Arabic letters, kutub al-mujūn ("books of shameless ribaldry”), and some said producers and publishers of such works ought to be punished ('Abd al-Tawwāb 14-15). Although early novelists and translators were disproportionately Syrian Christians, critics came from their ranks. In 1882, newspaper publisher Ya'qūb Șarrūf (1852-1927) stated, "If we were to study [the causes of] young men's and young women's perturbations, we would locate them mostly in premature love arising from reading novels and love poetry ... no one involved with raising children should give them any books other than those that train their minds and perfect their morals." Șarrūf's journal, Al-Muqtațaf, refused loftily to publish novels. But that soon changed, and twenty years after his anti-novel polemic, Șarrūf penned three novels of his own.

Some saw novels as sound replacements for the tales of ribaldry (though these tales were often sources for novels' motifs, episodes, narratorial strategies, and language). Meanwhile, novelists and translator-adaptors justified their practices on the basis of moral and didactic worth, either because they believed this or because it was a plausible argument that they and their readers could take comfort in. Some recognized novels as worthwhile simply for providing 
distraction from the stresses of modern life. ${ }^{6}$ But this did not mean they eschewed the didactic mission. The argument was about more than books: it concerned different models of tarbiya, a key concept and concern that governed many novels' prefaces and plots. Was it better to censor the young's reading as a way to shield them from less salutary behaviors, or to expose them to the range of human conduct while helping them to understand why some behaviors were preferable to others? Whatever the commentator's perspective, there was particular concern about the impact of novels on the young. That girls in particular were regarded as impressionable meant parents were warned to monitor their reading. But it also meant one could write novels with the moral training of "impressionable" girls and women in mind:

I have tried my utmost to avoid anything that would transgress proper comportment and the discipline of polite behavior; any man reading [my novel] could then put it in his wife's hands, I thought, or his sister's or daughter's ... if she could not read he could read it to her, so she could take as model the deeds of this lady Zenobia, leading character of this novel. (Quoted in 'Abd al-Tawwāb 23)

Thus did Ḥanūn Nammūr (dates?) present his novel, which (in case the message was not clear enough) he called Zaynūbiya namüḍhaj al-sayyidāt (1888, Zenobia, Ladies' Exemplar). Novels were written as vehicles for overt didactic commentary aimed at females. Women novelists often emphasized this aim, but women's magazines did not always approve of the conduct-novels penned by men. Anīs al-jalīs announced publication of Al-Ghäda al-mutanakkira (1901?, The Maiden in Disguise), by the pseudonymous Al-Bāḥith ibn al-'Așr [Researcher Son of the Age], a rejoinder to Qāsim Amīn's controversial book, Tahrīr al-mar'a (1899, The Emancipation of Women), which generated numerous responses. Anis al-jalīs's carefully worded critique of $\mathrm{Al}$ Ghāda showed how women had to walk a fine line between supporting novels as social commentary and objecting to misogynistic content: the author had "overstuffed his book with excessive words, exaggeratedly castigating women and [ascribing] a degree of treachery and fickle behavior to them. Such words ought not to issue from a refined, educated, decent person. Nevertheless, we thank him for writing, and speaking up. We can reach firm truths only across bridges like this novel" ("Kutub" 1901).

Sensitivity about girls' reading and having to defend their own and the genre's respectability obliged women novelists to foreground fiction's morally impeccable instructional credentials. But did this mean sanitizing content? Some argued within and through their novels 
that it was precisely young women who most needed to know about the world in all its messiness. These authors strenuously encouraged a critical female readership for the novel. Introducing her translation-adaptation Al-Ghāda al-injilīziyya (1895, The English Maiden), Hāshim addressed herself explicitly to women, constructing a female-only space in the relationship between author-narrator, reader, and character:

Ladies: Allow me to present to you this delicate maiden of mine: she is English but adorned with Arabic finery. I set her amongst you without worry that she will face scorn or trial. It is not that she claims infallibility or sinlessness-perfection is God's alone. She craves a bond with you, and why not, when her judge is the most eminent fair sex ... could she possibly fear reproach? Observe her closely with a critical eye and I will be grateful, as I will if you excuse my shortcomings, of which I am aware. (Quoted in 'Abd al-Tawwāb 91)

This crisp evocation of a feminine reading community encapsulates the approach of this first generation of Arab women novelists. Acutely aware of (middle-class) women's needs, aspirations and behaviors, they sought to create a critical female readership for reform-oriented fiction, and they represented fiction as essential to their reform-oriented goals - as both respectable and activist. They used modesty fiercely. They set their stories within social-political contexts that made clear the constraints within which their female characters acted. They enframed plots within articulations of what they faced as writers. Hāshim linked her (translated) heroine's situation to her own. Both desire, require, and feel vulnerable to the companionable critique of other women (so, then, should readers). The modesty discourse "cloaks" the writer as it announces gendered solidarity, plotted in these novels as a feminism equivocal yet loud.

\section{Translation}

Hāshim and other women wrote within a lively translation scene, and Arab women were among the translators. At least seventy French novels were translated in Egypt in 1870-1914, including works by women; more slowly, English novels appeared (Najm cited in Cachia 32-33). Reworkings of European fiction accustomed readers to new motifs and literary structures, even as commentators deplored the alleged effects on girls of "French novels," shorthand for "scandalous" romance fiction (although nineteenth-century British fiction was hardly "safer," saturated as it was with sensation and Gothic elements). Furthermore, translated plots could 
suggest to readers that Europeans struggled with issues similar to their own: translations might be read as critiques of local social usages. Translated romance fiction, maligned by commentators, spoke to hot-button issues, particularly marriage-partner choice and family coercion. In 1884, at a friend's request, the journalist Adīb Isḥāq (d. 1885) published a translation he had done "in the full bloom of youth" (Isḥāq 4). La belle parisienne (1864), by Comtesse Dash (Gabrielle Anna de Cisternes de Courtiras, 1804-72), a popular and prolific novelist in France, chronicled the marriage of a young couple where a disparity in family income, shrugged off generously by the bride's wealthy father, creates tensions. The author's prologue critiqued disparities in gendered education that led to marriage problems, a concern in the Arabic press by the early 1890s which undergirded calls for girls' education to produce companionate wives for the growing "market" of middle-class professional men. Ishāa's preface told readers that this was "in event, a love story; in outcome, a moral tale, by a khätūn (lady) of their nobility" (4). The novel was popular enough to see at least three printings: in 1902, Anīs aljalis announced its republication saying that it had been "widely and popularly received" (“Kutub” 1902).

Afìrīnū's translation, Shaqū' al-ummahāt, also was a good local fit. The setting is France, the characters French, but excepting details of sociality this could be an Arab story. Afïrīnū herself was a subject between cultures: of Lebanese origin, she spent much of her adulthood in Egypt, traveled to Europe, and married an Italian. In the novel, following her mother's death, sixteen-year-old Sūlanj (Solange) is married off by her father, "to lighten the burdens of raising and supervising her" (Afîrīnu 5). At a Paris soiree, Sūlanj gets a dark look from her husband when he sees her dancing with a young man. The scene seems calculated to fulfill nineteenthcentury Arab parents' fears of giving French novels full of dangerous ideas to their daughters! But this also made it a novel relevant to young Arab readers. Shaq $\bar{a}$ ' al-ummahāt narrates the costs to individuals and society of practicing coerced marriage; the disastrous pressures applied by husbands able to threaten removing children from their mothers; the vulnerability of young brides and mothers, and older women's acceptance of patriarchal practices to dominate and immiserate younger women. Sūlanj undergoes emotional and ethical agony, before ultimately being united with her true love.

Women gained experience at fiction writing through translation-adaptation. Esther Azharī Moyal (1873-1948), a Jewish Arab born in Beirut, founded one of the early Arab women's 
periodicals and is said to have translated fifteen novels. One of her earliest publications was the serialized Nanon, aw al-harb al-nisā' $\bar{\imath}$ [sic], which was adapted from Alexandre Dumas père's La Guerre des femmes (1845-46) and first appeared (unfinished) in seven installments in AlFatāt, then in her own periodical Al- 'Á'ila (1899-1902) in $1899 .{ }^{7}$ Hāshim adapted a novel by Arthur Conan Doyle that she called Riwāyat al-zawjayn (1908, The Married Couple). She described it as "a novel of morals and wise sayings, its expressions fashioned from the stuff of wisdom and moral precepts, worthy of taking as a foundation for married life, a guarantor of the desired felicity” (Hāshim, Riwayat 113). Farīda Yūsuf “Ațiyya (1867-1917), who wrote the novel Bayna 'arshayn (1912, Between Two Thrones), had translated Edward Bulwer Lytton's novel The Last Days of Pompeii (1834), titling it according to the traditional convention of rhymed prose, as Al-Rawḍa al-naḍira fi ayyām Bumbāy al-akhīra (1899, The Succulent Garden on the Last Days of Pompeii). Others focused wholly on translation. Announcing Faḍa 'il al-mar'a (1902, Woman's Virtues), Anīs al-jalīs lauded translator 'Afïfa Aẓan: “she has gained fame for her literary inclinations and her translations of fine novels: in this she is the most refined model that her likes amongst young women of the East could embrace. We acclaim her excellence and her interest in literature" ("Kutub" 1902). While female editors praised men's novels, they singled out women's, and pointedly suggested that readers follow their lead. ${ }^{8}$ They aligned women's translations with the reformist aims of their novel creations.

\section{Gender Politics and the Love Plot}

While the early novel's focus on gender relations addressed masculinity, it was most often on and through female bodies and feminine subjectivities that plots and resolutions operated. Titles are the most visible sign of this: a high proportion of novels bore the names of female protagonists or epithets of female sexual-social status and physical appearance, mostly referring to young, unmarried female protagonists. ${ }^{9}$ Such titles placed the lithe young female form centrally. For some, this was an instrumentalist focus. Zaydān explained that in his historical novels, "the reader reads with desire and pleasure, thinking he is delving into a love story when in truth he is reading about history, morals, customs and good character, all of which are difficult to access except in enormous volumes that the reader cannot apprehend without great labour and mental exercise. Historical novels are not amusements: they are one form of history" (“AlRiwāyāt"). 
Yet, as suggested, the love plot was more than sweetener: it encapsulated issues of political import, particularly tensions between individual choice and patriarchal family marriage arrangements, and the question of girls' educations. Novel after novel — whether set in other historical eras, in distant sites such as Europe (allowing "freer" treatment, as in Idlīd al-Bustānī’s story with its holidaying young people and tragic love triangle), or in the here-and-now of its writing - plotted this tension. Critique of arranged marriages as well as forced "unions" already oriented the novels of Salīm al-Bustānī and others. Thus, it was in a context where male authors' fictional constructions of feminine experience held center stage that women began to publish novels. What we can consider the first of these is a reminder that Arabic novels emerged from multiple roots, for it was set not within the debate between European fiction and local enterprise, but within earlier Arabic forms of writing, as its rhymed title suggests: Natā' $i j$ al-aḥwāl fí alaqwāl wa-l-af'āl (1887-88, Outcomes of Situations in Words and Actions).

The author, 'A' 'isha Taymūr (1840-1902), was born in Cairo into an eminent TurcoKurdish-Egyptian family close to Egypt's rulers; her father was a scholarly government official who preferred the bookish life and her mother was a freed Circassian concubine. She was tutored at home as a child, an education she resumed later in life, after domestic obligations eased and her husband died. She was amongst the first Arab women to be published in her lifetime and at her death was well known as a poet and prose writer. ${ }^{10}$

The main story narrates the coming-to-age of a young prince, Mamdūh, whose education has not been properly disciplined. His father's vizier and boon companion, Mālik and 'Aqīl, concerned about the kingdom's future, persuade the king to allow them to take over his training. Competition arises from officials running the military and the treasury, who try ruses to win over Mamdūh. This is a canny gender reversal: "trickery" in the oral storytelling tradition and canonical religious texts was often associated with females though stories abounded also of male futuwwa-tricksters. But makā'id al-rijāl (the trickery of men) (Taymūr 12), most often against the young and females, becomes a leitmotif in women's novels.

Stories that Mālik and 'Aqīl tell Mamdūḥ and a series of trials-by-journey-echoing the quest motif and picaresque element of earlier Arabic imaginative prose —educate Mamdūḥ into becoming a responsible individual who has learned the duty of care, the importance of listening, and the centrality of good judgment to the successful governance of a flourishing polity. Only then does he deserve marriage to the well-educated, deeply wise Būrān, daughter of the ruler of 
Persia, selected by Mamdūḥ's handlers as a woman who would positively influence the wayward young prince. The work argues for fiction as tarbiya with the role of the (female) writer inserted through a preface that advocates women's education and in periodic "invasions" or reminders of the author-narrator's presence, when characters call on her wisdom to make an aphoristic point: "Listen to what al-Taymūriyya says on this." Later writers continued to legitimize women as writers but differently, through prefaces calling directly on female readers rather than employing characters as "readers" of the text's author.

The work inhabits the pre-modern world of Islamic empires and the circulation of people, goods and stories therein, from Sind (present-day Punjab) to Persia to Sudan, and China, invoking the Islamic injunction to "seek knowledge even if that take you to China." Only by interacting in this multi-ethnic world can Mamdūh learn the art of ethical, Islamically legitimate community behavior and become a right ruler. The work's reliance on older genres - the picaresque maqama, the "mirrors for princes" genre, the embedded-story structure of Thousand and One Nights - is one aspect of its hybrid form. Another is its likely debt to translation, specifically Rifā‘a al-Ṭahțāwī’s 1867 translation of François de la Motte-Fénélon’s Les aventures de Télémaque, with its focus on the moral education of a prince as commentary on good governance (Hatem 56-57; Zeidan 62-63). In its emphasis on education and recognition of others' rights the work responds to nineteenth-century political concerns.

The importance of storytelling as a mode of imparting knowledge is a central theme. Connecting Taymūr's fiction to the Arabic novel's prehistory, this was also resonant in an era of suspicion about imaginative narrative as respectable literary endeavor. By emphasizing oral storytelling in the work's structure — storytelling propels the action forward-Taymūr suggests that forms of aesthetic expression seen as the antithesis of learned discourse not only entertained but could convey political and philosophical enquiry.

Rather than positioning a Taymūresque narrator, externalized yet peeking over characters' shoulders ready with a rhymed aphorism, Alīs al-Bustān̄̄'s only novel, Șầ'iba (1891, Correct or Astute [the protagonist's name]), relied strongly on dialogue, starting in media res with a conversation among women conveying the intimacy of domestic chat and drawing on the oral storyteller's strategy of direct address to listeners. A Christian Lebanese who moved to Egypt, al-Bustānī may have preferred to portray Muslim women at a geographical-ethnic distance to allow imaginative construction and defuse possible sensitivities over Christians 
critiquing Muslims, though "Islam" is not the issue. Men are. Istanbul as setting allowed another flexibility: elite women there had begun to practice more publicly visible sociabilities, evident in the novel's comings and goings, crucial to the plot. Female characters shop and picnic on the Bosphorus. Their relative freedom of movement as consumers highlights by contrast the truly narrow confines of expectation and opportunity experienced by Ottoman women of this era and class (Muslim, Christian, and Jewish).

Like Taymūr's, this novel centers tarbiya, equating undisciplined upbringing with "bad masculinity" while equipping heroines with strong moral and domestic-arts training plus the ability to read letters and novels. (Some women's novels do enact parents' worst nightmares: reading girls - these heroines are always readers - can and do write love letters!) Farīd grew up expecting to marry his cousin Șā'iba, educated thoroughly in the arts of Turkish rhetoric and home management, while he "had never gone beyond the basic reading and writing he had acquired. Chivalry and tales of love attracted him and he happily joined the companions of bad behavior" (9). By age seventeen, Farīd has squandered his inheritance. His mother-like Mamdūḥ’s wise handlers - believes marriage to a good woman will reform him, but cousin Șā'iba will not bow to custom. Though both mothers work on her, "she gave a firm no, arguing she was still young and had no inclination for marriage, while not mentioning anything that might lower or hurt him" (10). Too intelligent and well-trained to either fall for her cousin or insult him, Șā’iba tries to balance personal preference and moral outlook against kinship's claims.

While the tension between ideals of romantic love as the basis for successful marriage and the male first cousin's traditional right to marriage structures the plot, at the story's core is the fragility of trust in a context of deep-rooted suspicions about women's sexuality, impressionability and liability to be led astray, exactly the accusations leveled at the novel itself, especially its effects when in young women's hands. This novel is unusual as the story of a marriage, rather than a story culminating in marriage as the "happy ending" that is supposed to resolve and bring closure to a woman's life, as Zachs observes (345, 349-50). Al-Bustānī confronts marriage as a fragile structure requiring hard work to overcome destructive attitudes. As Zachs argues, the novel can be read as subversive. In particular, it challenges the prevailing (masculinist) reformist-critical vision that implied the partner-choice issue, and girls' education as the key to companionate marriages, were enough to create harmonious families. 
Eight years later came Fawwāz's novel Husn al- 'awāqib aw ghādat al-Zāhira (1899, Good Consequences, or the Maiden of Zahira). Fawwāz was unusual among female intellectuals. She was from neither an elite nor an intellectual background but rather a modest Shi' $i$ family from Jabal 'Amil, south Lebanon. She was taken into the service of the local emir's consort Fāțima bt. As'ad al-Khalīl (b. 1840). A poet, Fāṭima gave Zaynab her first taste of the literary life. Moving to Egypt, Fawwāz eventually published in nationalist newspapers and women's journals. She argued for women's access to waged employment, girls' education beyond the primary level, and women's participation in national dialogue (Booth, "Zaynab" and Classes 713, 18-19, 50-53, 87-90). The novel posed historical romance as educationally beneficial. Fawwāz drew on her own history, setting the novel in the time of her youth. The main characters are based on individuals she knew well, though characters and settings are lightly disguised (Booth, "Fiction's").

Like many early novels, this one's plot turns on drama and coincidence, taking protagonists galloping through the plains of Hawran, into Bedouin tents and southern Lebanese feudal homes, onto battlefields and into the shelter of accommodating herders' shacks. Fāri'a falls in love with cousin Shakīb, chosen successor to the ruler, their uncle. Another cousin, Tāmir, claims patriarchal right as eldest member of the younger generation. His struggle for the chieftainship yields a determination to have Fāri'a too, notably to strengthen his case, but then because her unwillingness feeds his lust and challenges his sense of gendered and family right. He abducts his cousin, raising the specter of non-consensual union. Just as al-Bustānī’s Farīd is ruthless about invading women's space and exploits this reckless and unwanted proximity to destroy a woman's honor and hence life, Tamir has no qualms about bursting in on Fāri'a. As in Taymūr's text, successful masculine political leadership must be based on responsible, respectful interaction with others, notably women as speaking members of the political community. Equally, the good man is a respectful partner in the family. It is no accident that the hero is seen falling in love with Fāri ‘a’s well-educated mind. In contrast, Tāmir’s desire, motivated initially by power-lust, is strengthened only by Fāri'a's physical attractiveness and refusals of his hand.

Six years later Fawwāz published her only other novel, Al-Malik Kürash awwal mulūk alfurs (1905, King Cyrus, First of the Kings of Persia). This reached much further back in history and was likely inspired by her reading while researching her biographical dictionary. Al-Malik begins with a brief history of the ancient Medean state. We meet Mandane, daughter of King 
Astyages, whose description echoes a common epithet from oral tales, sitt al-ḥusn wa-l-jamāl (lady of goodness and beauty) but yokes it to contemporary concerns: "He raised and educated her, bringing professors and instructors in all branches of knowledge. She excelled in every art and perfected every knowledge-discipline she encountered" (3).

The story of Mandane's marriage to Cambyses, the birth of Cyrus and his grandfather's persecution of him follows classical sources: Herodotus as then followed by a source Fawwāz used for her dictionary. But Mandane, and later Cyrus's intended, play larger roles. Where Fawwāz really breaks with the sources (and historical chronology), making Mandane a central character, is in adding a religious element. Mandane is an undercover leader of a clandestine band of monotheists, described anachronistically in the language of Islamic belief. The power of monotheistic piety and collective work on its behalf triumph. Mandane's work echoes the strong role women played in conversions in the first community of Muslims, though it seems bold to portray her as a religious leader who legislates for her fledgling secret community.

Cyrus's probity and piety emerge through contrast with other male characters, who steal women, regarding them as commodities or sexual objects rather than as thinking and feeling individuals. As in Husn al- 'awāqib, tyrannous rulers are disrespectful to and threatening toward women. Young Cyrus falls in love instantly with a woman who turns out to be the princess of Nineveh, and he despairs when he learns her lineage, for he believes himself the son of a shepherd. Thus the novel raises a topical concern: the status suitability of marriage partners. Honorable man that he is, Cyrus refuses to kidnap the princess: "I do not want to do as brigands do with free women; I want her to be my legal wife" (62). The moral universe of Islamic belief includes masculine responsibility to women as equal human beings.

Two years later Labība Hāshim published Shīrīn (1907), a novella based on another narrative of ancient Persia. The story is based loosely on that of Khosrow II Parviz (r. 590-628 $\mathrm{CE}$ ) and Shirin, as told by the Persian poet Nezami Gandavi in his poetic romance, Khosrow $o$ Shirin (1177-80, Khosrow and Shirin), and earlier in the Shahnameh of Firdawsi (Orsatti 2006). As in Cyrus, her story starts with a father-daughter axis, though an adoptive one. An Iranian noble, Ardeshir, returns from battle with a four-year-old orphan girl, Shirin, "beautiful to look at and sweet in her expressions, and so he loved her and undertook her education.” As she grows older, her "indications of goodness and beauty" come to the notice of Parviz, son of the Sasanian king, and "their pure emotions were bound by the chains of love" (121). Her adoptive father's 
disapproval introduces the struggle between love and patriarchal authority. Ardeshir is powerless to disturb the relationship, as Parviz is the king's son, but he forbids his daughter-ward to see him. "She was patient with his unjust treatment, making a show of her obedience and submission, though her heart was aflame ... she saw herself bound by the bonds of slavery" (122). Brought to his home as a captive, she is metaphorically captive to patriarchal prerogatives. That we are given no reason why Ardeshir should oppose this relationship highlights the arbitrariness or capriciousness of fathers dictating daughters' marriage choices. Shirin is a contemporary romantic heroine in historical-mythical guise.

Like Fawwāz, Hāshim also wrote fiction based on recent history: she had already published Qalb al-rajul (1904, Man's Heart). The title is unusual in situating men's emotions centrally; but women's sufferings are at the novel's affective heart. It takes place during and after the 1860s violence in Mount Lebanon pitting Druse against Christians. The story traces two generations of a family beset by displacements of kidnapping and then emigration, a love story wherein the young male protagonist's loyalties are torn by the pressures of having to make his way in the world. A story of origins suggests the mutability of "communal" identities as it displays the plight of women widowed by conflict — and links Hāshim's heroine, a destitute orphan, to those she invokes in her preface, the girls without family money whom she hopes to educate.

Hāshim creates characters with some interiority and emotional depth. She uses dialogue effectively, and resorts less frequently than Fawwāz or al-Bustānī to the intrusions of an external narrator. The novel presents the world of young, educated but marginalized migrants through embedded monologues of individual experience that draw on contemporary history. (A young Lebanese man on the train from Paris to Marseilles is traveling to Cairo to apply for translator posts the British colonial government has advertised for "Gordon Pasha's campaign to the Sudan" [62]). But this is also about female gullibility and the importance of being able to detect sincerity, to differentiate between fine words and true probity. Young women, whose perspective the narrative focalizes, must walk the difficult line between self-expression of their desires and transgressing strictures for proper femininity.

It is not governance and responsible masculinity that are paired but rather commerce, sincerity, and values of hard work, reflecting the commercial-professional bourgeoisie of the Syrian émigré community. The novel crafts material and social betterment as hinged on 
emotional honesty and care in relationships. A distinctly gendered outlook structures the story: the women are steadfast in their affections while the men, though strongly attached, are ready to replace one relationship with another. Such relationships are made within the context of tensions between social mores of Egypt and Lebanon, and local institutionalizations of European modernity (al-Bahrawi 10-11). Indeed, they allegorize the struggle with values that we observe as young 'Azīz's seeks a place amidst the political-economic fragility of colonial modernity, displaced onto a struggle with his divided affections, and consequent struggles for women, who can and do insist on their ethical stances but can intervene in the public world only by proxy. If they are the steadfast center of an ethical and emotionally satisfying life, the intertwining of assumptions of patriarchal privilege and the pressures of global-imperial capitalism make that life tenuous. Hāshim's novel stands out as an attempt at psychological depth and realistic portrayal.

Others more directly yoked public politics to issues of gender and women's aspirations. Adāl (Adele) Ya'qūb Jarīī̄nī (dates?) prefaced Al-Fatāt al-sharqiyya (1909, The Young Eastern Woman) by explicitly linking the new Ottoman constitution, the status of women, and writerly responsibility to communicate a social-critical perspective appealing "especially to women." Her novel was a product of a political moment, appearing soon after the Young Turk constitutional movement curtailed the Ottoman sultan's power (1908). This event gave rise to two other novels by women, Labība Mīkhā’̄il Șawāyā’s (1876-1918) Hasnā' Sālūn̄̄k (1909, The Beauty of Salonica) and 'Atiyya's Bayna 'arshayn. In this "age of light, through the blessing of the constitution" that had made appear "all the hidden factors behind our country's belated development," Jarīdīnī declared, patriots were obliged to investigate those factors. She turned immediately to the woman question:

Everyone knows the state of the eastern woman, and queries her position in the era of freedom and light. I decided to examine this through a realistic social perspective, leaving the philosophy of it to treatises, and poetic flights of fancy to books of ghazal and juvenalia. I put my research into novelistic form so it would touch every individual intimately, particularly girls of my kind (3).

Like Taymūr's, Jarīdīn̄̄'s modesty gesture (if I succeed it is due to my patriotic sensibility, and if I fail, it is my own flaws) explicates a gendered condition related to the novel's content. Education organizes the novel, from the historical framework that "prepares" the story, 
inscribing Beirut's growth as a commercial-cultural hub. The focus is on the three sisters whose mother attended the American School for Girls (described at glowing length) and who wants the same for her daughters; all three's educations and distinct paths are traced. Sāmia is sent to Paris, where she describes famous museums - including their holdings of ancient Levantine artifactsand offers a history of French cultural institutions, highlighting women's work founding and maintaining them. Thus, Jarīdīnī tries to demonstrate the value of offering females higher education as she feeds cultural knowledge directly to readers. Three years later, she returns home, shortly before her family moves to Egypt, and is married off to a young man who "delights in her graceful taste" (20).

Another daughter, Asmā', turns to medicine, her father's profession. Her travel to Europe affords an opportunity to speak back to Orientalist stereotypes. In England, "how astonished people were to hear that an easterner, a Syrian woman, wanted to join the students... they were all the more astonished when they heard her speak their language perfectly, as though she were one of their own daughters" (27). Younger sister Adiba hones her love of the Arabic language and "eastern customs," and "she inclined little to travel ... preferring to remain in Ottoman territories" (33).

The institutions of modern culture undergird these girls' story: newspapers celebrate the charity medical work of Asmā' and thus other girls learn of her. Young women's reading is pivotal in this novel as in others, whether of letters from sisters or lovers, newspapers, or didactic works (Jarīdīnī does not mention novels!). Adība spends "long hours" reading. "Every time she read the [ancient] female poets she wished fervently her own era would produce the like, wondering, 'Why don't we have these learned women now?'” Reading spurs her into reformist action. "Yes! I will stand and fight this ignorance, embarking on new work, that my classmates follow my example" (112). She founds a resoundingly successful women's magazine. But the ending leaves readers with an ambiguous message. Adība's personal unhappiness sends her into an emotional and physical tailspin, and a deathbed scene ends the novel (but for the didactic postface addressed to young women, clearly the author's designated readers). Jarīdīn̄̄'s is not the most successful novel, but as a programmatic three-daughter bildungsroman it says much about the era's preoccupations and fiction's conceptualization as a vehicle driving girls into a productive future: educated-and-domestic (Sāmia), educated-professional (Asmā'), or educatedactivist-intellectual (Adība). 
Also explicitly targeting a female audience was 'Afifa Karam (1883-1924), born in the Lebanese village of Amsheet. She married within her extended Maronite family and moved to the United States. She wrote for the New York Arabic newspaper Al-Hudā and in 1912 established her own magazine, Al- 'Alam al-jadìd. She also translated novels. Karam's first of five novels, Badī'a wa Fu'ād (1906, Badi'a and Fu'ad), begins with a "flock" of Lebanese village girls en route to the village spring. The Lebanese countryside's beauty figures the innocent loveliness of these girls — not yet weighted down by the full water-jugs they will carry back, emblematic of the burdens they will bear as single female émigrés.

Karam's novels assiduously maintain a didactic narratorial frame, punctuating the story regularly, sometimes blending authorial nostalgia and preaching:

A beautiful spot is dear Lebanon, and its beautiful, pure women are fresh lilies. But how regrettable! Look at her, how wilted she is, for the moist droplets of trained refinement are absent ... Our women are pretty, yes. Pure, yes. Good and intelligent, yes ... But what use is an implement if there is no hand to steer it or remove the rust? ... As much as the Lebanese value learning, they deny it to females" (38-9)

Our two protagonists, Badī'a and Lūsia, differ from the other girls at the village well, for they have been educated - and, we learn as the girls converse, they are to leave for America on the morrow. The immigrant experience frames this novel even in its village opening, suggesting how thoroughly that experience permeated Lebanese society. Badī‘a represents this experience poignantly, as the orphan girl who must make her way in the world alone. A complicated tale of class difference and self-making, the novel touches on familiar themes: young men's obliviousness (even when they care) to the additional and specific pressures young women face, and their resort to "ruses"; the weight of custom as falling more heavily on females; the importance of work and self-initiative; the question of balancing indigenous and imported practices; and the modeling of what the author proposes as ideal womanhood. Badi ' $a$ wa Fu'ād indicts the prevailing discourse on gender identities, sexuality, honor and blame. Though heavyhanded - a conduct-book lightly clothed in a plot and set of characters - it is clever and compelling in playing out patriarchal views that blamed women for men's sexual behaviors and social shortcomings. As in some other novels, women on their own make the long trip away from the land of their birth, portrayed as the site of practices deleterious to women. The theme of the journey allows cultural comparison, but this highlights that the major tensions arise internally, 
within the home country, inscribing forms of estrangement and rebellion. On the surface $\operatorname{Bad}^{\prime}{ }^{\prime} a$ wa Fu'ād concerns behavior, but it is about women's freedoms and rights (Al-Dab'16).

Karam's second novel, Fạtima al-badawiyya (n.d., Fatima the Bedouin), is the improbable tale of a young Syrian Bedouin woman who is seduced by an urbane SyrianChristian man and ends up as an abandoned single mother on Broadway. ${ }^{11}$ This novel establishes a trans-cultural context of women's oppression through the voluble friendship of Fātima and Alīs (Alice), a privileged American woman who has undergone her own sufferings. As in Hāshim's Qalb al-rajul, in Karam's novels there are some forthright statements that are inescapably feminist, as is the consistent focus throughout most of these novels by women on "honor" as a ruse deployed to control women's bodies and minds. But the novel's frontispiece reminds us of the ways an anti-patriarchal discourse had to be embedded. Under the author's portrait runs a quotation from her: "The suckling child is the man or woman of the future only if it is on the breast of a woman of trained refinement and excellence" (frontispiece). Dedicating the novel to

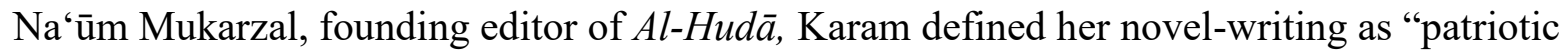
service" aiming — with Mukarzal's guidance — to "break the traditional shackles and [instead] become bound by the ties of knowledge; to aim for civilizational progress and true learned refinement in the hearts of émigré women.” But were these women to find self-realization ultimately in motherhood?

Karam's novels exhibit the ambiguities or tensions of early Arab feminist discourse, as, in other ways, do the other novels discussed here. On the one hand, through plots, character portrayal and didactic framing, they highlight the ways gender assignment and expectations placed on females straighten their lives and opportunities, and-in the name of "honor" and paternal right - disallow their freedoms of choice and disavow their voices. On the other hand, they uphold the era's discourses of domestic duty which-however much they foreground and laud female ability and energies - tended to buttress discourses of male authority in the family and polity. This double-voiced perspective (also evident in narrative trajectories juxtaposing young women's accomplishments with early death as the price they pay) ran throughout the discourses of early Arab feminism. ${ }^{12}$

${ }^{1}$ Zachs and Halevi offer a publication context for Masarra's letter. On "Hinrī wa-Imīliyā" see Hayek. 
${ }^{2}$ In 1913-21, women published no novels we know of; in the 1920s, pseudo-autobiographical writing prevailed (Booth, "Between"). In the early 1930s, women again published novels.

${ }^{3}$ Buthayna Sha‘bān claimed that Zaynab Fawwāz's Husn al- 'awāqib (1899) was the first Arabic novel, but there are no grounds for this (Sha'bān 15-17, 37-38, 47-48; she backtracks slightly 6364). She claims to have "discovered" early women's fiction, apparently unaware of Zeidan's pioneering study.

${ }^{4}$ On Afîrīnū, see Booth's May, 45-46, 75-76, 122-23, 174-75.

${ }^{5}$ Volume one featured her Shirin, three short stories she translated, and three composed or translated by others (two men and one woman, Salwā Buṭrus Salāma).

6 'Abd al-Tawwāb traces these views, 16-32.

${ }^{7}$ Moyal's preface in Al-Fatāt 1: 4 (1 March 1893) mentions only the author, but this is certainly the work in question, based on my research. On the fifteen novels, see Khairallah (cited in Levy 158, n56). Lital Levy notes that this translation was amongst Moyal's early published writings (136). While it is not included in the copy of Al- 'A' 'ila which I have consulted, the 15 July 1899 issue refers to it this way: "Notice: Due to the large amount of material in this issue, we had to postpone the novel section [malzamat al-riwāya] to the coming issue" (97).

${ }^{8}$ Aẓan also translated two unnamed works as Al-Marqīza Matildā, șidq al-widād (1896, The Marquise Mathilde, True Love), and Badr al-tamām aw shahīd al-sirr (1898, Full Moon, or Secret Witness) ('Abd al-Tawwāb 25, 105, 178).

9 'Abd al-Tawwāb's extensive though incomplete bibliography lists 233 novels published in the period, of which 77 use solely female epithets or proper names as titles (171-84).

${ }^{10}$ On Taymūr, see Booth, “'Ā'isha” and Hatem.

${ }^{11}$ Karam refers to this novel in her preface as her second. Her third was Ghādat 'Amshīt (1914, The Maiden of Amsheet).

${ }^{12}$ I am grateful for the help of Joseph Zeidan and Mustafa Sadiq in acquiring sources. All translations are mine. Work for this chapter was carried out whilst I was Senior Humanities Research Fellow at the Humanities Institute, New York University Abu Dhabi. I am grateful for this research support. 


\section{Works Cited}

'Abd al-Tawwāb, Muḥammad Sayyid. Nazariyyāt al-riwāya al-'arabiyya: Al-Muqaddimāt al-ulā min sanat 1858-1914. Cairo: Al-Hay’a al-'Āmma lil-Kitāb, 2010.

Afìrīnū, Aliksandra (Alexandra Avierino). Riwāyat shaqā' al-ummahāt. Alexandria: Maṭba'at Jarīdat al-Bașīr, n.d. [1901]. First published as annexes to Anīs al-Jalīs vol. 2 (1900).

Al-Baḥrāwī, Sayyid. Muḥtawāa al-shakl fì al-riwāya al- 'arabiyya 1. Al-Nuṣūṣ al-miṣriyya al-ūlā. Cairo: Al-Hay’a al-‘Āmma lil-Kitāb, 1996.

Al-Bustān̄̄, Alīs Buṭrus. Riwāyat Șā'iba. Beirut: Al-Matba'a al-Adabiyya, 1891.

Al-Ḍab', Mușțafā. “Badī 'a wa Fu'ād wa su'āl al-bidāyāt.” In Karam, Badī 'a, 5-30.

Allen, Roger. The Arabic Novel: An Historical and Critical Introduction. 2d ed. Syracuse: Syracuse UP, 1995.

Al-Ma'lūf, Qayṣar. Al-Ghāda al-sūriyya fì al-diyār al-amrīkiyya. Cairo: Maṭba'at al-Muqtațaf wa-l-Muqațtam, 1902.

“Āthār adabiyya.” Fatāt al-sharq 1: 8 (15 May 1907): 248.

'Ațiyya, Farīda Yūsuf. Bayna 'arshayn. Tripoli: Maṭba'at al-Najāḥ, 1912.

---, trans. Al-Rawḍa al-naḍ̄ira fi ayyām Bumbāy al-akhīra. Cairo: Al-Hilāl, 1899.

Aẓan, 'Afīfa. Al-Marqīza Matildā, șidq al-widād. Cairo: Maṭba'at al-Ahrām, 1896.

---. Badr al-tamām aw shahīd al-sirr. Cairo: Maṭba'at al-Ahrām, 1898.

---. Faḍ̄ 'il al-Mar'a. Cairo: Maṭba'at al-Ahrām, 1902.

Baron, Beth. The Women's Awakening in Egypt: Culture, Society and the Press. New Haven: Yale UP, 1994.

Booth, Marilyn. “"A’isha 'Ismat bint Isma'il Taymūr.” In Essays in Arabic Literary Biography 1850-1950. Ed. Roger Allen. Weisbaden: Harrassowitz Verlag, 2010. 366-76.

---. "Between the Harem and the Houseboat: Fallenness, Gendered Spaces and the Female National Subject in 1920s Egypt.” In Harem Histories: Envisioning Places and Living Spaces. Ed. Marilyn Booth. Durham Duke UP, 2010. 342-73.

---. Classes of Ladies of Cloistered Spaces: Writing Feminist History through Biography in Finde-siecle Egypt. Edinburgh: Edinburgh UP, 2015.

---. May Her Likes Be Multiplied: Biography and Gender Politics in Egypt. Berkeley: U of California P, 2001.

Cachia, Pierre. An Overview of Modern Arabic Literature. Edinburgh: Edinburgh UP, 1990. 
Dash, La Comtesse. La Belle Parisienne. Paris: Michel Lévy Frères, 1864.

Fawwāz, Zaynab. Riwāyat ḥusn al- 'awāqib aw ghādat al-Zāhira. Cairo: Maṭba at Hindiyya, 1899.

---. Riwāyat al-malik Kürash awwal mulūk al-furs: wa hiya riwāya adabiyya gharāmiyya tārīkhiyya. Cairo: Maṭba'at Hindiyya, 1905.

Hallaq, Boutros, and Heidi Toelle. "Introduction." In Histoire de la littérature arabe modern.

Vol. 1: 1845-1945. Ed. Boutros Hallaq and Heidi Toelle. Paris: Sindbad/Actes Sud, 2007.

Hāshim, Labība. Qalb al-rajul. Cairo: Maṭba'at al-Ma'ārif, 1904.

---, trans. Al-Ghāda al-injilìziyya (1895). Cairo: The National Center for Translation, 2008.

---. "Riwāyat al-zawjayn.” Fatāt al-sharq 3: 3 (Dec 1908): 113-20.

---. Shīrīn. Fatāt al-sharq 1: 4 (15 Jan 1907): 121-8; 1:5 (15 Feb. 1907): 153-60; 1: 6 (15 March 1907): 185-92; $1: 7$ (15 April 1907): 217-24.

Hatem, Mervat F. Literature, Gender, and Nation-Building in Nineteenth-Century Egypt: The Life and Works of 'A 'isha Taymūr. London: Palgrave, 2011.

Hayek, Ghenwa. "Experimental Female Fictions; Or, the Brief Wondrous Life of the Nahḍa Sensation Story." Middle Eastern Literatures 16: 3 (2013): 249-65.

Isḥāq, Adīb. Qiṣsat al-bārīsiyya al-ḥasnā’ ta 'līf al-Kūnta Dāsh. Beirut: Maṭba'at al-Qiddīs Jiyurjiyus [St Georgius), 2d pr, 1888.

Jack, Belinda. The Woman Reader. New Haven: Yale UP, 2012.

Jarīdīn̄i, Adāl Ya'qūb. Riwāyat al-fatāt al-sharqiyya. Beirut: Maṭba'at al-Tawfīq, 1909.

Karam, 'Afīfa. Badī'a wa Fu'ād. New York: Maktabat Jarīdat Al-Hudā, 1906. Republished in Cairo: Al-Hay’a al-‘Āmma lil-Kitāb, 2006.

---. Fāțima al-badawiyya. New York: Maktabat Jarīdat Al-Hudā, n.d.

---. Ghādat 'Amshīt. New York: Maktabat Jarīdat Al-Hudā, 1914.

Khairallah, K. T. “La Syrie.” Revue du monde musulman 19 (Apr-June 1912): 1-143.

“Kutub al-shahr wa jarā'iduhā.” Anīs al-jalīs 4: 7 (31 July 1901): 783.

“Kutub al-shahr wa jarā'iduhā.” Anīs al-jalīs 5: 4 (30 April 1902): 1037.

“Kutub al-shahr wa jarā’iduhā.” Anīs al-jalīs 5: 5 (31 May 1902): 1105.

Levy, Lital. "Partitioned pasts: Arab Jewish Intellectuals and the Case of Esther Azharī Moyal (1873-1948).” In The Making of the Arab Intellectual (1880-1960): Empire, Public 
Sphere, and the Colonial Coordinates of Selfhood. Ed. Dyala Hamza. New York:

Routledge, 2012. 128-63.

Masarra, Wastīn. "Al-Tarbiya." Al-Jinān 2: 2 (15 Dec 1871): 54-56.

Moosa, Matti. The Origins of Modern Arabic Fiction. 2d ed. Boulder: Lynne Reinner, 1997.

Nājīi, Sawsan. Al-Mar'a fì al-mir'āt: Dirāsa naqdiyya lil-riwāya al-nisā'ìyya fì Mișr 1888-1985.

Cairo: Al-‘Arabī lil-Nashr wa-1-Tawziī‘, n.d. [1989].

Najm, Muḥammad Yūsuf. Al-Qișsa fì al-adab al- 'arabī al-ḥadīth 1870-1914. 3d pr. Beirut: Dār al-Thaqāfa, 1966.

Nammūr, Ḥanūn, Zaynūbyā namūạhaj al-sayyidāt. Alexandria: Armūniya newspaper, 1888.

Orsatti, Paola. “Kosrow o Širin.” Encylopedia Iranica Online. 15 August 2006. iranicaonline.org/articles/Kosrow-o-sirin. Accessed December 2, 2014.

Șarrūf, Ya'qūb. "Ḍarar al-riwāyāt wa-l-ash 'ār al-ḥubbiyya." Al-Muqtațaf 7: 3 (August 1882): 174.

Șawāyā, Labība Mīkhā’̄il. Hasnā’ Sālūnīk. Damascus: Al-Maṭba'a al-Bațriyārkiyya alUrthūọhuksiyya, 1909.

Sha'bān, Buthayna. Mi'at 'àm min al-riwāya al-nisā' 'iyya al-'arabiyya. Beirut: Dār al-Ādāb, 1999.

Taymūr, 'A' isha 'Ișmat. Natā'ij al-ahwāl fì al-aqwāl wa-l-af'āl. Cairo: Matba'at Muhammad Afandī Mușțafā, 1887-88.

Zachs, Fruma. "Subversive Voices of Daughters of the Nahda: Alice al-Bustānī and Riwayat Șā'iba (1891)." Hawwa 9 (2011): 332-57.

--- and Sharon Halevi. 'From Difa 'al-nisa' to mas'alat al-nisa' in Greater Syria: Readers and Writers Debate Women and their Rights, 1858-1900.” International Journal of Middle East Studies 41 (2009): 615-33.

Zaydān, Jurjī. "Muqaddima." Al-Hilāl 4: 1 (Sept. 1895): 23.

---. "Al-Riwāyāt al-tārīkihiyya." Al-Hilal 5: 1 (Sept. 1896): 24.

Zeidan, Joseph. Arab Women Novelists: The Formative Years and Beyond. Binghamton: SUNY $\mathrm{P}, 1995$. 